\title{
Aktualisasi Pendidikan Agama dan Sains dalam Character Building Peserta Didik di Sekolah dan Madrasah
}

\author{
Firman Mansir \\ Universitas Muhammadiyah Yogyakarta, Indonesia \\ firmanmansir@umy.ac.id
}

\begin{abstract}
This research was conducted to analyse what methods are effective in analysing the Role of Religion and Science Education in Forming Student Character Building. Basically, learning is influenced by the determination of the selection of the method used. Islamic religious education and science are different lessons so that as educators need to channel their creativity in delivering material. In this research, the writer used literature review method. So that the results of the study refer to methods that are effectively used. In the analysis of the role of religion and science education in shaping the character building of students. The result of this research is an effective method that can be used by educators in the role of religious education and science. In the formation of character building is the mix method, namely the problem-solving method, the inquiry method and the Discovery method.

Keywords: Science; Islamic Education; Character Building
\end{abstract}

Abstrak: Penelitian ini dilakukan untuk menganalisis metode apa yang efektif pada analisis Peran Pendidikan Agama dan Sains Dalam Membentuk Character Building Peserta Didik. Pada dasarnya suatu pembelajaran dipengaruhi oleh ketetapan pemilihan metode yang digunakan. Pendidikan Agama Islam dan sains merupakan pelajaran yang berbeda coraknya sehingga sebagai pendidik perlu menyalurkan kreatifitas dalam menyampaikan materi. Dalam penelitian kali ini, penulis menggunakan metode literatur review. Sehingga hasil dari penilitian mengacu pada metode yang efektif digunakan dalam analisis peran pendidikan agama dan sains dalam membentuk character building peserta didik. Hasil dari penelitian adalah metode yang efektif yang bisa digunakan pendidik dalam peranan melalui Pendidikan Agama dan sains dalam pembentukan character building adalah mix method yaitu metode ploblem solving, metode inquiry dan metode Discovery.

Kata kunci: Sains; Pendidikan Agama Islam; Character Building

Copyright (C) J-PAI: Jurnal Pendidikan Agama Islam. All Right Reserved.

This is an open-access article under the CC BY-SA license

(https://creativecommons.org/licenses/by-sa/4.0/).

Correspondence Address: jpai@uin-malang.ac.id 
J-PAI: Jurnal Pendidikan Agama Islam, Vol. 7 No. 2 Januari-Juni 2021

\section{A. PENDAhuluan}

Isu Pendidikan terus menjadi perbincangan dari hari ke hari, hal ini ditengarai oleh makna pendidikan yang merupakan suatu usaha sadar dari pemerintah sebagai upaya penciptaan generasi yang mampu bersaing dengan seiringnya perkembangan zaman. Pendidikan ini juga sebagai bentuk dalam mewujudkan cita-cita negara yang tertuang dalam pembukaan UUD 1945 yaitu " mencerdaskan kehidupan bangsa”. Dalam dunia pendidikan, semua pihak bekerja sama saling bahu membahu demi terciptanya program pendidikan yang sesuai dengan kondisi negara Indonesia, yang nantinya diharapkan program-program ini mampu menjadi sebuah gebrakan baru dalam dunia pendidikan.

Pendidikan agama merupakan dasar dari seorang manusia, karena manusia yang memiliki agama seharusnya adalah manusia yang hidupnya memiliki arti dan memiliki prospek ke depan, dalam artian bukan hanya kehidupan dunia tetapi juga kehidupan akhirat. Pendidikan agama Islam merupakan proses kegiatan pembelajaran dan penambahan informasi mengenai agama Islam serta penanaman nilai-nilai Islam di lingkungan pendidikan. Pendidikan agama Islam seharusnya mampu menutupi dari setiap kegiatan proses pembelajaran, karena kelengkapan dasar Islam sendiri yang harusnya menjadi pokok dalam melakukan segala kegiatan. Dalam Islam, dasar setiap kelakuan atau tindakan merujuk pada al-Quran dan al-Hadis yang terjaga keasliannya dan masih murni dari ajaran nabi Muhammad SAW dari zaman terdahulu. Selain itu, kedua dasar ini juga menjawab semua persoalan duniawi maupun ukhrawi sesuai dengan perkembangan zaman. Pendidikan mempunyai peranan penting dalam membangun kecerdasan sekaligus kepribadian anak manusia menjadi lebih baik. Oleh karena itu, pendidikan secara terusmenerus dibangun dan dikembangkan agar dari proses pelaksanaan menghasilkan generasi yang diharapkan (Putra, 2017).

Seiring dengan perkembangan zaman yang begitu pesatnya menandakan bahwasanya sains di dunia sedang gencar-gencarnya memperoleh tempat pertama di kalangan masyarakat. Banyak barang-barang yang tercipta karena sains, selain barang sains juga menjadi obat logika masyarakat dalam berbagai bidang. Sains kini menjadi terobosan baru di kalangan dunia dalam hal apa pun. Semua yang dilakukan manusia, semua yang diciptakan manusia adalah melalui sains. Banyak teori-teori bermunculan karena hasil pemikiran para ahli, kemudian tidak jarang dari banyaknya teori yang muncul mengakibatkan perbedaan pendapat tapi masih dengan dasar yang jelas yaitu sains. Banyak manusia zaman sekarang yang mengedepankan logika daripada hal abstrak, itu dikarenakan seiring perkembangan zaman otak manusia juga semakin berkembang.

Pemikiran-pemikiran manusia juga ikut mengikuti perkembangan zaman yang ada. Pada masa ini bisa dibilang sedang penjajakan di masa revolusi industri 4.0, di mana sekarang mesin sudah bertebaran dimana-mana, termasuk pada peralatan rumah tangga yang dipakai sehari-hari. Pada masa ini jika manusia tidak bisa mengikuti perubahan zaman, maka manusia itu yang akan kalah atau tersingkir secara hukum alam. Tujuan dari adanya proses kegiatan pembelajaran sains sendiri adalah sebagai bentuk upaya dalam mewadahi peserta didik dalam mempelajari diri sendiri dan juga lingkungan alam sekitar (Mansir et al., 2020).

\section{B. METODE}

Adapun metode yang digunakan dalam penelitian ini adalah penelitian kepustakaan yaitu merupakan model penelitian yang didasarkan pada studi literatur dengan melalui metode pengolahan data dan pengumpulan pustaka dengan cara mencari referensi dari 
Firman Mansir: Aktualisasi Pendidikan Agama dan Sains dalam Character Building...

penelitian terdahulu yang tentunya berhubungan dengan fokus yang dibahas serta topik dalam penelitian ini. Oleh karena itu, teori kepustakaan dalam penelitian ini yang memfokuskan pada penemuan studi maupun teori dan tidak menafikan penemuan gagasan penelitian sebelumnya yang kemudian digunakan sebagai analisis dan pemecahan rumusan masalah dari penelitian dengan pendekatan kualitatif. Subjek dari penelitian merupakan para pengajar atau pendidik dalam melakukan perannya melalui Pendidikan Agama dan Sains dalam pembentukan Character Building kepada peserta didik.

\section{HASIL DAN PEMBAHASAN}

Character Building adalah upaya sadar yang dilakukan guna menanamkan nilai karakter yang nantinya akan membangun jati diri seluruh anggota dalam satuan pendidikan. Komponen yang perlu diperhatikan dalam upaya penanaman nilai karakter yaitu berupa pengetahuan, kesadaran atau kemauan, dan tindakan untuk melaksanakan nilai-nilai tersebut (Chusnani, 2013). Pada era seperti ini penguatan pendidikan karakter perlu dan sangat penting digalakkan sebagai upaya bela negara agar tidak lunturnya karakter-karakter bangsa sebagai salah satu bentuk cinta negara Indonesia. Pendidikan karakter memiliki tujuan supaya peserta didik yang mana berperan sebagai calon generasi penerus bangsa agar memiliki moral dan akhlak yang memadai, sehingga diharapkan dapat menciptakan kehidupan berbangsa dan bernegara yang adil, menawarkan rasa aman serta kemakmuran (Putri, 2018).

Penanaman character building sedari dini seharusnya menjadi wacana nasional dalam dunia pendidikan. Dasar dari pendidikan karakter sendiri sudah tercantum dalam kitab suci al-Qur'an yaitu Q.S 31:17“Hai anakku, dirikanlah Shalat dan suruhlah manusia mengerjakan yang baik dan cegahlah mereka dari perbuatan yang mungkar dan bersabarlah terhadap apa yang menimpa kamu. Sesungguhnya yang demikian itu termasuk hal-hal yang diwajibkan oleh Allah". Dari terjemahan surah di atas dijelaskan bahwasanya dalam Islam sendiri penanaman karakter sudah digencarkan yaitu dari seruan berbuat kebaikan, pelarangan berbuat yang munkar. Secara tegas dalam Islam dijelaskan bahwa seorang ayah memberikan pendidikan karakter dengan seruan untuk melaksanakan shalat.

Persoalan mengenai karakter dan moralitas merupakan kasus yang kompleks dan sekaligus menjadi sebuah keprihatinan yang mendalam bagi semua kalangan. Banyak kasus seperti peperangan antar etnis, bullying antar individu, pembunuhan karena hal sepele, pencurian, dan lainnya merupakan bukti bahwa masih tipisnya karakter manusia, bahkan krisis moralitas sering kali dilihat di lingkungan sekitar. Seperti contoh seorang tetangga yang menyebar luaskan fitnah kepada tetangga yang lainya. Baru-baru ini kasus yang sangat memprihatinkan dan sangat tidak manusiawi yaitu korupsi dana bantuan Covid19 masyarakat oleh menteri Sosial sendiri. Bukankah itu menjadi suatu hal yang tabu dan sangat mengerikan, apalagi kasus tersebut dilakukan oleh menteri sosial yang seharusnya memiliki jiwa kesosialan yang tinggi, empati yang besar dan hati yang luas dan lapang. Kasus-kasus ini sudah cukup menjadi bukti bahwa pemerintah Indonesia yang seharusnya menjadi contoh nyata masyarakat, malah menjadi benalu bagi negara.

Pemerintah sendiri sebenarnya sudah menyerukan program PKK yaitu Penguatan Pendidikan Karakter sebagai upaya dalam penanaman karakter kepada peserta didik. Tujuan dari adanya program PKK ini merupakan pemberdayaan atas nilai moral yang diharapkan mampu menjadi sebuah budaya di sekolah. Tujuan lain dari adanya PKK ini juga sebagai pendorong terciptanya pendidikan yang berkualitas dan bermoral secara merata atau menyeluruh sampai ke ujung bangsa. Dari kasus yang sudah dipaparkan oleh penulis, 
seyogyanya Penguatan Pendidikan Karakter tidak hanya digencarkan di dunia pendidikan sekolah saja, namun harus lebih digiatkan lagi dilingkungan pemerintah itu sendiri, apalagi pemerintah itu sebagai pembuat dan pencipta peraturan.

\section{Peran Pendidikan Agama Islam dan Sains}

Peranan guru dalam proses pembangunan karakter siswa semakin berat dan complicated (Putri, 2018). Guru bukan hanya memberikan konsep karakter tetapi juga mengarahkan peserta didik agar bisa mengimplementasikan pada keseharian. Karena guru adalah panutan maka dari itu guru harus bisa mencontohkan penerapan karakter dari dalam dirinya sendiri. Pada penelitian ini, pendidik dituntut untuk menggunakan dirinya sebagai metode dan media pembelajaran dalam kegiatan proses pembelajaran, yaitu sebagai role model bagi peserta didik. Selain itu pendidik menggunakan metode problem solving sebagai upaya pembangunan karakter berupa kepercayaan diri dalam pengimplementasian pada kehidupan sehari-hari.

Setiap manusia mempunyai karakternya tersendiri yang tentunya berbeda antara satu dengan yang lainnya. Hal ini dipengaruhi karena faktor lingkungan di mana mereka memperoleh atau menjalankan proses pembelajaran di tempat yang berbeda. Sehingga hal ini dapat disimpulkan bahwa peran lingkungan pendidikan sangat berpengaruh dalam pembentukan karakter peserta didik (Mansir, 2018). Pada penelitian ini penulis menggunakan metode hubungan sebab akibat yang bersumber dari literature review. Pembangunan karakter dalam perspektif agama merupakan pembangunan akhlak jika diartikan dengan Islam (Mansir, 2020). Maka dari itu peran guru agama sangat berpengaruh dalam hal character building peserta didik dilingkungan sekolah (Adu, 2014).

Program penguatan karakter berbasis religiusitas di lingkungan sekolah sangat meningkatkan mutu sekolah, dimulai dari pembiasaan kepada peserta didik kemudian peran guru agama dalam penanaman pemahaman karakter kepada peserta didik (Suryanti \& Dwi, 2018). Karakter merupakan hal sangat penting yang harus ditanamkan dalam diri setiap manusia. Penerapan karakter harus ditanamkan secara sadar dan terencana. Pendidikan agama sangat berperan penting dalam pembentukan karakter karena di segala aspek atau strata kehidupan agama selalu hadir (Anwar, 2016). Pembentukan karakter merupakan sifat bawaan (fitrah) dari manusia, sehingga pemilihan lingkungan dan pendidikan sangat berperan sebagai upaya pengembangan dari karakter yang telah dimiliki oleh seseorang dan menentukan akhir dari proses pemilihan tersebut (Mansir, 2021).

Oleh karena itu, dalam konteks ini diperlukan model pembelajaran SSCS. Model ini merupakan model yang fokusnya terdapat pada pemecahan permasalahan dan meningkatkan pengetahuan keterampilan dalam pemecahan masalah. Dari masalah ini kemudian diharapkan peserta didik mampu meningkatkan karakter seperti rasa ingin tahu yang lebih dari sebelum diadakan penelitian ini (Assidiqi, 2015). Penelitian ini menggunakan metode penelitian SSCS atau secara kompleks menggunakan metode problem solving. Dalam menumbuhkan nilai karakter peserta didik, diperlukan beberapa strategi seperti moral knowing, moral modeling, moral feeling and loving, moral acting dan moral habituasi (Cahyono, 2016).

Masyarakat yang mulanya sebagai makhluk primitif kini menjadi manusia yang berperadaban dengan adanya perkembangan zaman sebagai tanda bahwa sains sudah sangat berkembang (Izzah, 2018). Pada mulanya mata pelajaran sains hanyalah terfokus pada penguasaan materi saja, namun dengan metode hands-on dan minds-on yang 
diterapkan oleh pengajar menumbuhkan karakter peserta didik seperti rasa keingintahuan yang lebih, menumbuhkan rasa percaya diri, meningkatkan kekreativitasan dan inovasi, menjadikan peserta didik berkepribadian jujur, mandiri dan bertanggung jawab (Chusnani, 2013). Integrasi pendidikan sains dan agama memiliki arti bahwa penguasaan dan percampuran antara pengetahuan melalui pandangan sains dengan nilai Islam dan kepribadian Islam (Pratiwi, 2014).

Adapun metode yang dapat digunakan seorang pendidik dalam melaksanakan proses kegiatan belajar mengajar Pembelajaran Agama Islam yaitu :

a) Metode ceramah

Merupakan metode dengan model lisan, yaitu pendidik menjelaskan secara lisan dan rinci kepada peserta didik mengenai agama Islam

b) Metode Tanya Jawab

Merupakan metode dengan model berupa seorang pendidik dan peserta didik saling berinteraksi dan saling lempar pertanyaan serta jawaban seputar pendidikan agama Islam

c) Metode Latihan

Pendidik memberikan pemahan terlebih dahulu secara singkat kepada peserta didik kemudian memberikan soal sebagai bentuk latihan peserta didik, misalnya latihan penyelenggaraan jenazah dan lainnya.

d) Metode Problem Solving (Pemecahan Masalah)

Pendidik memberikan sebuah masalah kemudian memberikan kesempatan kepada peserta didik untuk mencari solusi dari masalah yang sudah di berikan, khususnya seputar agama Islam.

e) Metode Inquiry

Yaitu metode kesadaran dari peserta didik mengenai apa saja yang didapatkan dalam proses kegiata pembelajaran agama Islam.

\section{f) Metode Discovery}

Yaitu metode mandiri, dimana peserta didik dituntut untuk mencari jawaban atas pertanyaan yang muncul dari dirinya sendiri, metode ini menjadikan peserta didik kreatif dan aktif dalam kegiatan proses belajar pada persoalan Fiqh, Aqidah Akhlak dan Sejarah Kebudayaan Islam.

Dari analisis data yang diperoleh sebagai literatur dan digunakan sebagai referensi penelitian ini dapat disimpulkan bahwasanya dalam penelitian terdahulu sudah lumayan cukup dibahas ataupun di perhatikan oleh para pakar. Dengan pembuktian berupa beberapa literatur yang penulis jadikan referensi dan saling berkesinambungan dalam pembahasan fokus yang sama. Beraneka ragam macam metode yang berbeda dalam setiap penelitian sebelumnya menandakan bahwasanya efektivitas peran pendidikan agama dan sains dalam pembentukan character building dapat dilaksanakan dengan berbagai cara dan luasnya ranah yang dapat dicakup. Contohnya ketika dalam salah satu penelitian mengambil objek yaitu di ranah lingkungan dan strategi, jadi bukan hanya terfokus dalam ranah efektivitas saja. Kurangnya dari penelitian yang sebelumnya yaitu mengenai metode yang sebaiknya digunakan oleh seorang pendidik dalam perannya melalui pendidikan agama dan sains sebagai upaya pembentukan moral atau karakter peserta didik.

Dari beberapa uraian mengenai macam metode yang bisa digunakan oleh seorang pendidik di atas, dan dari hasil analisis data penelitian terdahulu bahwasanya penulis menyimpulkan metode yang efektif dalam proses peranan pendidik melalui pendidikan agama dan sains sebagai upaya pembentukan Charakter Building peserta didik adalah mix 
method. Di Dalam hal ini, mix method disini adalah gabungan dari metode pembelajaran problem solving dengan metode inquiry dan metode discovery. Mix method ini menurut penulis disebut tepat digunakan dalam proses pembelajaran karena dengan metode ini karakter peserta didik dapat terbentuk akibat dari proses yang ada di dalam ketiga metode ini.

Metode problem-solving menuntut peserta didik untuk menganalisis dari adanya permasalahan yang ada untuk mencari jalan keluar dari masalah tersebut (Setiawan et al., 2020). Korelasinya dengan character building yaitu dengan metode ini peserta didik dipacu untuk menumbuhkan karakter berupa pemikiran kritis, pemikiran kritis ini diperoleh ketika peserta didik menganalisis dari permasalahan yang muncul.

1. Metode Discovery, metode ini menuntut peserta didik mencari jawaban atas pertanyaan yang muncul dari dalam dirinya sendiri. Korelasinya dengan Character Building yaitu menciptakan peserta didik yang mandiri.

2. Metode inquiry, metode ini menjadikan peserta didik sadar akan pentingnya apa yang sudah dipelajarinya. Korelasinya dengan Character Building yaitu menumbuhkan kesadaran peserta didik akan pentingnya pengalaman yang sudah dilaluinya, kemudian peserta didik dapat mengambil pembelajaran dari pegalaman belajar tersebut. Menjadikan peserta didik memiliki sifat lebih mengargai apa yang sudah dimiliki.

Sebagai seorang pendidik, menanamkan nilai-nilai moral sudah sepantasnya dilakukan dan diterapkan di dalam kepribadiannya, dilaksanakan di setiap kesehariannya dan menjadikan dirinya sendiri sebagai role model bagi para muridnya (Mansir, 2021). Karena peran pendidik sangat mempengaruhi penilaian dan tingkah laku peserta didik. Selain berperan di dalam kelas pada saat proses kegiatan belajar mengajar, guru juga berperan penting di luar kelas, karena guru dalam pundaknya menyangga nama profesi serta sebagai ujung tombak yang baik dan terhormat (Mansir, 2020). Layaknya dalam arti guru dalam bahasa Jawa yaitu digugu (dipatuhi/dihormati) dan ditiru (dicontoh). Maka dari itu sudah menjadi kewajiban seorang pendidik untuk menjaga setiap ucapan dan tingkah lakunya, apalagi di lingkungan umum yang bersifat publik.

\section{KESIMPULAN}

Dari berbagai macam metode yang digunakan oleh peneliti terdahulu disimpulkan bahwasanya penulis menyatakan metode yang efektif dalam peran Pendidikan Agama dan Sains dalam pembentukan Character Building yaitu mix method, dengan menggabungkan metode problem solving, metode inquiry dan metode discovery. Peran pendidik dalam pembentukan Character Building ini sangat penting. Selain itu, metode ini merupakan metode yang tepat diimplementasikan ke dalam diri seorang pendidik yaitu menjadikan dirinya sendiri sebagai role model bagi para peserta didik, karena sorang pendidik adalah panutan bagi para peserta didik. Keharusan dalam menjaga citra seorang pendidik harus ditanamkan dalam jiwa seorang pendidik sebagai karakter yang harus dimiliki oleh setiap pendidik. 
Firman Mansir: Aktualisasi Pendidikan Agama dan Sains dalam Character Building...

\section{DAFTAR PUSTAKA}

Adu, L. 2014. Pendidikan karakter dalam perspektif Islam. Biosel: Biology Science and Education, 3(1), 68-78. http://dx.doi.org/10.33477/bs.v3i1.511.

Anwar, S. 2016. Peran Pendidikan Agama Islam Dalam Membentuk Karakter Bangsa AlTadzkiyyah. Jurnal Pendidikan Islam, https://doi.org/https://doi.org/10.24042/atjpi.v7i2.1500

Assidiqi, H. 2015. Membentuk karakter peserta didik melalui model pembelajaran search, solve, create, and share. Math Didactic. Jurnal Pendidikan Matematika Dan IPA, 1(1), 4555. https://doi.org/https://doi.org/10.33654/math.v1i1.94

Cahyono, H. 2016. Pendidikan Karakter: Strategi Pendidikan Nilai Dalam Membentuk Karakter Religius. Ri'aya Jurnal Sosial Dan Keagamaan, 1(2), 230. https://doi.org/https://doi.org/10.32332/riayah.v1i02.116

Chusnani, D. 2013. Pendidikan Karakter Melalui Sains. Jurnal Kebijakan Dan Pengembangan Pendidikan, 1(1). https://doi.org/10.22219/jkpp.v1i1.1502.

Izzah, I. 2018. Peran Pendidikan Agama Islam Dalam Membentuk Masyarakat Madani. $\begin{array}{llll}\text { PEDAGOGIK: } \quad \text { Jurnal Pendidikan, } & 5(1),\end{array}$ https://doi.org/https://doi.org/10.33650/pjp.v5i1.219

Mansir, F. 2018. Diskursus Pendidikan Karakter di Peguruan Tinggi Keagamaan Islam pada Era Milenial. Tadrib: Jurnal Pendidikan Agama Islam, 4(2), 280-300. https://doi.org/10.19109/tadrib.v4i2.2560.

Mansir, F. 2020. The Leadership of Personnel Management in Islamic Education: Emerging Insights from an Indonesian Universiti. Edukasia Islamika: Jurnal Pendidikan Islam 5(1), 1-16. https://doi.org/10.28918/jei.v5i1.2349.

Mansir, F. 2021. Analisis Model-Model Pembelajaran Fikih Yang Aktual dalam Merespons Isu Sosial di Sekolah dan Madrasah. Ta'dibuna: Jurnal Pendidikan Islam, 10(1), 88-99. http://dx.doi.org/10.32832/tadibuna.v10i1.4212

Mansir, F., Purnomo, H., \& Tumin, T. 2020. Penerapan Pembelajaran Pendidikan Agama Islam Berbasis Sains Budaya Lokal Di Sekolah Dan Madrasah. Tarbawy : Indonesian Journal of Islamic Education, 7(1), 70-79. https://doi.org/https://doi.org/10.17509/t.v7i1.23478

Pratiwi, U. 2014. Integrasi Pendidikan Agama-Sains Berbasis Eksperimental Untuk Membentuk Character Building Mahasiswa. Jurnal Pemikiran Alternatif Kependidikan Insania, 19(2). https://doi.org/. https://doi.org/10.24090/insania.v19i2.720

Putra, P. 2017. Implementasi Pendidikan Karakter dalam Pembelajaran Aqidah Akhlak (Studi Multi Kasus di MIN Sekuduk dan MIN Pemangkat Kabupaten Sambas). $A L$ BIDAYAH: Jurnal Pendidikan Dasar Islam 9(2). https://doi.org/10.14421/albidayah.v9i2.14

Putri, D. P. 2018. Pendidikan Karakter Pada Anak Sekolah Dasar Di Era Digital. AR-RIAYAH $\begin{array}{llll}\text { Jurnal Pendidikan } & \text { Dasar, } & 2(1), & \end{array}$ https://doi.org/https://doi.org/10.29240/jpd.v2i1.439

Setiawan, B., Rachmadtullah, R., \& Iasha, V. 2020. Problem-Solving Method: The Effectiveness of The Pre-service Elementary Education Teacher Activeness in The Concept of Physics Content. Jurnal Basicedu, 4(4), 1074-1083. https://doi.org/10.31004/basicedu.v4i4.484.

Suryanti, E. W., \& Widayanti, F. D. 2018. "Penguatan Pendidikan Karakter Berbasis Religius", CIASTECH 2018. 254. http://publishing-widyagama.ac.id/ejournalv2/index.php/ciastech/article/view/630. 